\section{DiscoverSys \\ Published by DiscoverSys \\ Willingness of private general practitioners to refer suspected tuberculosis patients in Badung District}

\author{
Ni Putu Eka Purnama Dewi, ${ }^{1 *}$ Anak Agung Sagung Sawitri, ${ }^{2,3}$ \\ Ni Wayan Arya Utami ${ }^{2,4}$
}

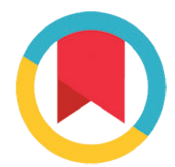

CrossMark

\section{ABSTRACT}

Background and purpose: The national tuberculosis (TB) prevalence study showed that between 2013 and 2014 there was significant proportion of pulmonary TB patients received treatment from private healthcare facilities. Data from Bali Province and Badung District Health Offices revealed that of all suspected TB patients only a few were referred by their private general practitioner. A reward system was created in 2012 by providing credit points to every referral made by the private general practitioner. This study aims to examine association between the reward system, national health insurance scheme and willingness to refer suspected TB patients.

Methods: A cross-sectional study was conducted from February to April 2017. A total of 111 private general practitioners who practice at Badung District were interviewed. In addition, medical record from these private general practitioners were also examined.

Results: Our study found that as many as 55 (45.95\%) of private general practitioners had ever referred suspected TB patients over the last year. The total suspected TB patient being reffered in the last year was 132 cases. A cross checking with the laboratory data revealed that only 47 cases (35.61\%) presented at referral laboratory facilities. Multivariate analysis showed that the willingness of private general practitioners to refer suspected TB patient was associated to reward system ( $A O R=4.62 ; 95 \% \mathrm{Cl}: 1.23-17.32)$ and supervision from TB officials ( $A O R=13.07 ; 95 \% \mathrm{Cl}$ : 3.78-45.13). The enrollment of private general practitioners as a primary healthcare facility under the national insurance scheme was not associated with the willingness to refer suspected TB patients.

Conclusions: About half of the private general practitioners have ever referred a suspected TB patient. Supervision from TB officials and a reward system in terms of credit points were associated with the willingness to refer suspected TB patients. Ongoing supervision, providing credit points, and improving referral systems are required to improve case findings and referral of suspected TB patients by private general practitioners.
'Badung District Health Office, ${ }^{2}$ Public Health Postgraduate Program Udayana University, ${ }^{3}$ Department of Community and Preventive Medicine Faculty of Medicine Udayana University, ${ }^{4}$ School of Public Health, Faculty of Medicine Udayana University

${ }^{*}$ Correspondence to:

Ni Putu Eka Purnama Dewi, Badung District Health Office

ekapede83@yahoo.co.id

Keywords: private general practicitioner, suspected tuberculosis patient, Bali Province

Cite This Article: Dewi, N.P.E.P., Sawitri, A.A.S., Utami, N.W.A. 2017. Willingness of private general practitioners to refer suspected tuberculosis patients in Badung District. Public Health and Preventive Medicine Archive 5(2): 105-111. D0I:10.15562/phpma.v5i2.23

\section{INTRODUCTION}

Total estimated number of TB cases globally in 2015 were 10.4 million, but total reported TB cases in the same year were only 6.1 million, indicating about 4.3 million cases were unreported and most of them from India, Indonesia and Nigeria. ${ }^{1}$

Based on total and new cases, Indonesia is the second largest global contributor after India. ${ }^{1}$ TB prevalence in Indonesia was 596 per 100,000 population in 2015. This prevalence was higher than the global TB prevalence of 390 per 100,000 population. ${ }^{1}$ Furthermore, TB incidence in Indonesia was 395 per 100,000 population in 2015 - more than double of the the global TB incidence of 142 per 100,000 population. ${ }^{1}$

The global TB case notification rate (CNR) was $58.65 \%$. Indonesia is classified as a country with a low CNR. ${ }^{1}$ CNR is used as a national indicator for TB case finding. The Indonesian Ministry of Health $(\mathrm{MoH})$ mandated the passive case finding by healthcare facilities to improve CNR through establishment of TB service networks involving private and public sectors - public-private mix (PPM). ${ }^{2}$ The CNR for Bali Province was only 70 per 100,000 population - much lower than the national CNR of 135 per 100,000 population in 2015. ${ }^{3,4}$ In addition, the target for CNR in Badung District was 60 per 100,000 population in 2015, while the actual CNR was slightly lower (54 per 100,000 population). ${ }^{5}$

One strategy pursued by the government to improve TB case finding is involving private healthcare facilities in case detection as well as TB treatment. ${ }^{6}$ The national TB prevalence study between 2013-2014 revealed that as many as 36.5\% of respondents who have diagnosed with pulmonary TB were treated by private healthcare facilities. ${ }^{7}$ Reports from Bali Province and Badung District health Offices showed that of total suspected TB cases found in 2015, 2\% was contributed by private general practitioners (PGP). ${ }^{4,5}$ This proportion is very low in comparison to Asian countries where the contribution of PGP as high as $30 \%{ }^{8}$ 
In order to improve case finding by PGP, Bali Province Government implemented reward systems by providing credit points to PGP for every suspected TB referral. ${ }^{9}$ This reward system targeting PGP was developed based on recommendation of a study conducted in 2007 on referral of suspected TB patients in Bali Province. ${ }^{10}$ Bali Provincial Government and Indonesian Medical Association Bali Chapter took this recommendation and signed an agreement document outlining reward systems by providing creadit points to PGP. This reward system was officially enacted in $2012 .{ }^{9}$

Information regarding this reward system was distributed through medical associations, meetings and trainings which involve PGPs. In parallel to this activity, skills of PGPs on TB Directly Observed Treatment Shortcourse (TB DOTS) was intensified through five days face-to-face training. ${ }^{11}$ An online training of 12 weeks was also conducted from 2015. In addition, supervision from $\mathrm{TB}$ officials was also intensified to monitor TB treatment and reporting mechanisms. ${ }^{11}$

This study aims to identify the number of PGP who refer and patients being referred to the laboratory. In addition it also examines the association between the willingness of PGP to refer suspected TB patients and reward system, supervision from TB official, capacity building and participation of PGP in national health insurance scheme.

\section{METHODS}

A cross-sectional study was conducted in Badung District. A total of 111 PGPs were randomly selected from 171 registered PGPs in Badung District. Data were collected from February to April 2017 through interviews and medical notes of each patient were also explored. This medical notes were then compared to data at the referral laboratory to identify patients who did not come for laboratory test. Variables included socio-demographic, training on TB DOTS, knowledge on TB, supervision from TB officials, duration of practice as a private GP, total hours of daily practice, total patients per week, role as medical doctor at a community health centre or hospital which provides TB DOTS, access to TB microscopic laboratory, logistical support from TB program, participation as primary healthcare facility under the national health insurance scheme, and reward system in terms of credit points. Logistical support was defined as any supports received by PGP including anti-tuberculosis drugs and non-drugs supports. Participation under the national health insurance scheme was defined as: PGP who apply and fulfill all requirements and qualified as a primary healthcare facility under the scheme. The qualified PGPs will provide services to all population who are the member of the national health insurance. Level of knowledge on TB was assessed by scoring each answer provided by respondents. Total knowledge score was calculated by total correct score of each respondent' divided by total score multiply by a 100 . Several aspects assessed on knowledge included symptoms and signs of TB, TB diagnostic, laboratory tests for diagnostic, TB follow up, and indicators for treatment efficacy.

Data were analysed by univariate, bivariate and multivariate techniques. Chi-square test was applied for the bivariate analysis and logistic regression was applied for the multivariate analysis. This study protocol has been approved by the Human Research Ethics Committees Faculty of Medicine Udayana University/Sanglah General Hospital Denpasar.

\section{RESULTS}

Median age for all respondents was 39 years and as many as $51.35 \%$ were males. All respondents were medical doctor, as many as $14,41 \%$ completed training on master of health sciences, and one respondent completed training on doctorate in health sciences.

As can be seen in Table 1, as many as 51 PGPs (45.95\%) ever referred suspected TB patients in the last year and 56 PGPs (54.05\%) never referred suspected TB patients because they did not have any suspected TB patients. Four PGPs were willing to refer TB patients but the patients refused to be referred. The total suspected TB patients being referred in the last year was 132 cases, with median of two cases, minimal referral of one case and the maximum referral was 12 cases. A cross-checking was performed with the laboratory data. It revealed that only 47 cases actually visited the laboratory for sputum test (35.61\%) - comprised of referral from 28 PGPs.

Table 2 shows the distribution of PGPs based on level of knowledge on reward system and tuberculosis, supervision from TB officials, and participation on a meeting or training program. Of all PGPs who found suspected TB patients in the last year, as many as $85.45 \%$ were informed about the reward systems while only $52.73 \%$ ever received credit points; $65.45 \%$ ever attended a meeting or training on TB; and $85.45 \%$ ever received supervision from TB officials. However, only $43.64 \%$ of respondents were having sufficient knowledge on TB.

Table 3 shows a cross tabulation between willingness to refer suspected TB patients and several independent variables. It can be observed that several variables were positively associated with 
Table 1 Case finding and referral of suspected TB patients for sputum test by private general practitioner (PGP) to assigned laboratory in the last year

\begin{tabular}{lc}
\hline Variables & $\mathbf{n}(\%)$ \\
\hline PGP found suspected TB patient & $55(49.55)$ \\
$\quad$ Yes & $51(92.73)$ \\
$\quad$ Referred & $4(7.27)$ \\
$\quad$ No (because the patients refuse to be referred) & $56(50.45)$ \\
$\quad$ No & $1-12$ \\
Minimum-maximum suspected TB patients found & 132 \\
Number of suspected TB patients being referred & 2 \\
Median suspected TB patients being referred & $47(35.61)$ \\
Number of suspected patients presented at assigned & \\
laboratory & \\
Number of PGPs whose patients presented at assigned & \\
$\quad$ Yes & $28(54.90)$ \\
$\quad$ No & $23(45.10)$ \\
\hline
\end{tabular}

Table 2 Number PGPs who found suspected TB patients by TB knowledge, reward systems, supervision and training

\begin{tabular}{lc}
\hline Variables & $\begin{array}{c}\text { PGPs who identified suspected TB patients } \\
\mathbf{n}(\%)\end{array}$ \\
\hline TB knowledge & $24(43.64)$ \\
Good & $31(56.36)$ \\
Poor & \\
Reward system (credit points) awareness & $47(85.45)$ \\
Yes & $8(14.55)$ \\
No & \\
Ever received reward (credit points) & $29(52.73)$ \\
Yes & $26(47.27)$ \\
No & \\
Ever attended TB meeting or training & $36(65.45)$ \\
Yes & $19(34.55)$ \\
No & \\
Supervision by TB officials & $47(85.45)$ \\
Yes & $8(14.55)$ \\
No & $55(100.00)$ \\
Total &
\end{tabular}

the willingness of private GP to refer suspected TB patients which included: being informed on the reward system $(p<0.001)$, ever received credit points as reward $(\mathrm{p}<0.001)$, ever attended meetings or trainings on TB $(\mathrm{p}<0.001)$, ever received supervision from TB officials $(\mathrm{p}<0.001)$, total patients per week ( $\mathrm{p}=0.017)$, duration of practice per day $(\mathrm{p}=0.064)$, and available logistical support from TB program $(\mathrm{p}<0.001)$.
Multivariate analysis with backward method included five variables in the final model as can be seen in Table 4. The willingness of private GPs to refer suspected TB patients to laboratory facilities was significantly associated with reward system $(\mathrm{AOR}=4.62$; 95\%CI: $1.23-17.32)$ and supervision by $\mathrm{TB}$ officials (AOR=13.07; 95\% CI: 3.78-45.13).

\section{DISCUSSION}

Our study identified that only about half of PGPs in Badung District had ever found suspected TB patients in the last year and almost all of them had referred suspected TB patients to the assigned laboratory. However, the number of suspected patients being referred was small (2-3 patients per doctor per year). Among patients being referred, only one third presented at the assigned laboratory. Low number of suspected TB patients referred by PGPs may related to the low TB prevalence in this area. Provincial Health Department report shows that number of confirm TB patients from Badung District was only 325 patients in 2015.

The low proportion of patients presented at the assigned laboratory may related to patient's willingness to go to laboratory for sputum test. It may also related to the referral system of suspected TB patients. In Badung District, out of 17 assigned laboratories, only two provide pick-up service to collect specimen from PGPs or patient's houses.

The proportion of PGPs who found suspected TB patients also low in other area. Previous study in Denpasar City found that only $35.1 \%$ of PGPs ever identified suspected TB patients in the last three months. However, the proportion of PGPs who referred the suspected TB patients in both studies were quite high, $92.73 \%$ in our study and $81.10 \%$ in Denpasar. ${ }^{12}$ Our finding is lower when compared to a study in Jogyakarta in 2004 which identified as many as $63.40 \%$ of PGPs found suspected TB patients in the last year, but the proportion of PGPs who referred suspected TB patients is similar. ${ }^{13}$ The different proportion of PGPs who found suspected TB patients in the two studies may related to TB prevalence and local health systems. Study in India in 2002 also shows that similar proportion of PGPs had ever identified and reffered suspected TB patients. $^{14}$

Our study found that reward system was associated with the participation to refer suspected TB patients. Studies have also revealed that providing rewards for health providers can improve participation of private facilities on TB case finding and notification. ${ }^{15,16}$ Other study in Denpasar City conducted in 2013 revealed that as many as $86.9 \%$ of PGPs underscored the importance of reward 
Table 3 Association between referring suspected TB patient and several variables

\begin{tabular}{|c|c|c|c|c|}
\hline \multirow[b]{2}{*}{ Variables } & \multicolumn{2}{|c|}{ PGPs who referred suspected TB patients } & \multirow[b]{2}{*}{ Total (\%) } & \multirow[b]{2}{*}{ p value } \\
\hline & Yes (\%) & No (\%) & & \\
\hline \multicolumn{5}{|l|}{ Reward system awareness } \\
\hline Yes & $43(70.49)$ & $18(29.51)$ & $61(54.95)$ & $<0.001$ \\
\hline No & $8(16.00)$ & $42(84.00)$ & $50(45.05)$ & \\
\hline \multicolumn{5}{|l|}{ Ever received reward (credit points) } \\
\hline Yes & $26(78.79)$ & $7(21.21)$ & $33(29.73)$ & $<0.001$ \\
\hline No & $25(32.05)$ & $53(67.95)$ & $78(70.27)$ & \\
\hline \multicolumn{5}{|l|}{$\begin{array}{l}\text { Primary healthcare provider under } \\
\text { National Health Insurance Scheme }\end{array}$} \\
\hline Yes & $33(50.00)$ & $33(50.00)$ & $66(59.46)$ & 0.299 \\
\hline No & $18(40.00)$ & $27(60.00)$ & $45(40.54)$ & \\
\hline Age, median (IQR) & $41(12)$ & $37(18.5)$ & $39(16)$ & $0.151^{*}$ \\
\hline \multicolumn{5}{|l|}{ Sex } \\
\hline Female & $26(48.15)$ & $28(51.85)$ & $54(48.65)$ & 0.650 \\
\hline Male & $25(43.86)$ & $32(56.14)$ & $57(51.35)$ & \\
\hline \multicolumn{5}{|l|}{ Education } \\
\hline Postgraduate (health major) & $6(35.29)$ & $11(64.71)$ & $17(15.32)$ & 0.338 \\
\hline Medical doctor & $45(47.87)$ & $49(52.13)$ & $94(84.68)$ & \\
\hline \multicolumn{5}{|l|}{ Ever attended TB meeting/training } \\
\hline Yes & $33(68.75)$ & $15(31.25)$ & $48(43.24)$ & $<0.001$ \\
\hline No & $18(28.57)$ & $45(71.43)$ & $63(56.76)$ & \\
\hline TB knowledge, mean $( \pm \mathrm{SD})$ & $61.41( \pm 9.81)$ & $59.24( \pm 10.42)$ & $\begin{array}{c}60.33 \\
( \pm 10.15)\end{array}$ & $0.263^{*}$ \\
\hline \multicolumn{5}{|l|}{ Supervision by TB officials } \\
\hline Yes & $43(76.79)$ & $13(23.21)$ & $56(50.45)$ & $<0.001$ \\
\hline No & $8(14.55)$ & $47(85.45)$ & $55(49.45)$ & \\
\hline Total patients/week, median (IQR) & $92(90)$ & $70,5(56)$ & $81(65)$ & $0.017^{\star}$ \\
\hline $\begin{array}{l}\text { Duration of practice as private GP, } \\
\text { median (IQR) }\end{array}$ & $10(13)$ & $9(13)$ & $10(13)$ & $0.312^{*}$ \\
\hline $\begin{array}{l}\text { Duration (hour) of practice/day, } \\
\text { median (IQR) }\end{array}$ & $6(1)$ & $6(1.5)$ & $6(1)$ & $0.064^{*}$ \\
\hline \multicolumn{5}{|l|}{ Working at DOTS services } \\
\hline Yes & $26(50.00)$ & $26(50.00)$ & $52(46.85)$ & 0.421 \\
\hline No & $25(42.37)$ & $34(57.63)$ & $59(53.15)$ & \\
\hline \multicolumn{5}{|c|}{ Received materials support from TB program } \\
\hline Yes & $41(75.93)$ & $13(24.07)$ & $54(48.65)$ & $<0.001$ \\
\hline No & $10(17.54)$ & $47(82.46)$ & $57(51.35)$ & \\
\hline \multicolumn{5}{|l|}{ Access to assigned laboratory } \\
\hline $\begin{array}{l}\text { Distance from the practice to } \\
\text { laboratory }(\mathrm{km}) \text {, median (IQR) }\end{array}$ & $3(3)$ & $3(3)$ & $3(3)$ & $0.513^{*}$ \\
\hline $\begin{array}{l}\text { Traveling time from the practice to } \\
\text { laboratory (minutes), median (IQR) }\end{array}$ & $10(10)$ & $10(10)$ & $10(8)$ & $0.934^{*}$ \\
\hline
\end{tabular}


Table 3 Continue

\begin{tabular}{|c|c|c|c|c|}
\hline \multirow[b]{2}{*}{ Variables } & \multicolumn{2}{|c|}{ PGPs who referred suspected TB patients } & \multirow[b]{2}{*}{ Total (\%) } & \multirow[b]{2}{*}{ p value } \\
\hline & Yes (\%) & No (\%) & & \\
\hline \multicolumn{5}{|l|}{ Public transport } \\
\hline Available & $9(45.00)$ & $11(55.00)$ & $20(18.02)$ & 0.925 \\
\hline Not available & $42(46.15)$ & $49(53.85)$ & $91(81.98)$ & \\
\hline \multicolumn{5}{|c|}{ Pick up service from the laboratory } \\
\hline Yes & $3(37.50)$ & $5(62.50)$ & $8(7.21)$ & 0.619 \\
\hline No & $48(46.60)$ & $55(53.40)$ & $103(92.79)$ & \\
\hline Total & $51(45.95)$ & $60(54.05)$ & $111(100.00)$ & \\
\hline
\end{tabular}

${ }^{*}$ calculated using logistic regression

Table 4 Adjusted odd ratio (AOR) between the willingness of private GP to refer suspected TB patient and several independent variables (the final model)

\begin{tabular}{lccc}
\hline Variables & AOR & $\mathbf{9 5 \% C l}$ & p value \\
\hline Age & 0.95 & $0.89-1.02$ & 0.146 \\
Well-informed on the reward system (credit points) & 4.62 & $1.23-17.32$ & 0.023 \\
Attending TB meetings or training & 1.97 & $0.63-6.21$ & 0.247 \\
Supervision from TB officials & 13.07 & $3.78-45.13$ & 0.000 \\
Duration of practice per day & 1.27 & $0.96-1.68$ & 0.098 \\
\hline
\end{tabular}

system by providing credit points for PGPs who participated in TB control programs. ${ }^{12}$

Our study also found that supervision by TB officials is associated with participation to refer suspected TB patients, even though the supervision is inadequate. Supervision in Badung District is conducted by TB officials from public health centres only once, and supervision by district and provincial health office only done to two PGPs per three months. The supervision covers several issues including interview with PGP related to TB management in their private practice and examines their recording and reporting, TB contact book, as well as logistic availability.

This finding also consistent with other studies. A study conducted in Bali Province in 2007 found that supervision from $\mathrm{TB}$ officials increased the likelihood of referral of suspected TB patients by PGPs by 2.9 times. ${ }^{10}$ Other study in the Philippines conducted in 2006 also revealed similar trend supervision from TB officials improved participation of PGPs on TB case finding and notification. ${ }^{17}$

Suspected TB patients being referred by PGPs in this study might be under-estimate. It is due to several PGPs combined the record between general patients and suspected TB patients resulted in difficulty to examine referred TB records. In addition, several PGPs also did not record referred patients accordingly.

Implementation research is warranted to improve referral mechanisms for suspected TB patients from PGPs in order to increase total number of patients who actually accessed laboratory facilities for the sputum test. In addition, continuity of the reward system by providing credit points for participated PGPs and adequate supervision from TB officials are also essential to improve participants of PGPs to refer suspected TB patients.

\section{CONCLUSION}

Although only half of PGPs had found suspected TB patients, the proportion of PGPs who referred suspected TB patients is relatively high. Data from laboratory facilities, however indicate a high proportion of referred patients did not visit assigned laboratory. Providing reward in terms of credit points for participated PGPs as well as adequate supervision from TB officials can improve participation of PGPs on TB case finding and notification.

\section{ACKNOWLEDGEMENT}

We would like to thank the Head of Badung District Health Office, Badung Chapter Indonesian Medical Association, and all respondents who had participated in this study.

\section{REFERENCES}

1. World Health Organization. Global tuberculosis report 2016. Genewa: World Health Organization; 2016.

2. Ministry of Health of Indonesia. Peraturan Menteri Kesehatan Republik Indonesia Nomor 67 Tahun 2016 tentang penanggulangan tuberkulosis [The Ministry of Health of Indonesia Regulation No. 672016 on Tuberculosis Control]. Jakarta: Ministry of Health of Indonesia; 2016. 
3. Ministry of Health of Indonesia. Profil kesehatan indonesia tahun 2015 [The 2015 Indonesia health profile]. Jakarta: Ministry of Health of Indonesia; 2016.

4. Bali Province Health Office. Profil Dinas Kesehatan Propinsi Bali Tahun 2015 [The 2015 Bali Province Health Profile]. Denpasar: Bali Province Health Office; 2016.

5. Badung District Health Office. Laporan tahunan program pengendalian tuberkulosis (TB) tahun 2015 [The 2015 report on tuberculosis control program]. Mangupura: Badung District Health Office; 2016.

6. Ministry of Health of Indonesia. Pedoman nasional pengendalian tuberkulosis [National Guideline on Tuberculosis Control]. Jakarta: Ministry of Health of Indonesia; 2014.

7. Ministry of Health of Indonesia. Survei prevalensi tuberkulosis Indonesia 2013-2014 [Tuberculosis prevalence survey in Indonesia 2013-2014]. Jakarta: Ministry of Health of Indonesia; 2015

8. Newell J. The implications for TB control of the growth in numbers of private practitioners in developing countries. Bulletin of World Health Organization. 2002; 80: 836-837.

9. Bali Provincial Government and Bali Chapter Indonesian Medical Association. Perjanjian Kerja Sama Gubernur Bali dengan Ketua Ikatan Dokter Indonesia (IDI) Wilayah Bali Nomor: 075/14/PKS/B.PEM/VIII/2012-153/IDI/BALI / VIII/2012 tentang Pelaksanan Kegiatan Tuberculosis dengan Directly Observed Treatment Shortcourse (TB DOTS) [Partnership agreement document between Bali Governor and the head of Indonesia Medical Association Bali Chapter on Directly Observed Treatment Shortcourse (TB DOTS)]. Denpasar: Bali Provincial Government and Bali Chapter Indonesian Medical Association; 2012.

10. Putra IWGAE, Utami NWA, Suarjana IK, et al. Factors associated to referral of tuberculosis suspects by private practitioners to community health centres in Bali Province, Indonesia. BMC Health Services Research. 2013; 13: 445.
11. Bali Province Health Office. Profil Dinas Kesehatan Propinsi Bali Tahun 2007 [The 2007 Bali Province Health Profile]. Denpasar: Bali Province Health Office.; 2008.

12. Putra, I. W. G. A. E., Astuti, P.A.S., Kardiwinata, M.P., Duana, I.M.K., and Astiti, C.I.D. The association of participation credit points awardedfor private practitioners on tb cases finding in Denpasar, Bali Indonesia. Denpasar: Udayana University; 2013.

13. Mahendradhata Y, Utarini A, Lazuardi U, et al. Private practitioners and tuberculosis case detection in Jogjakarta, Indonesia: Actual Role and Potential. Tropical Medicine \& International Health. 2007; 12: 1218-1224.

14. Arora VK, Sarin R, Lönnroth K. Feasibility and Effectiveness of a public-private mix project for improved TB control in Delhi, India. International Journal of Tubercolosis and Lung Disease. 2003; 7: 1131-1138.

15. Syafar M. Kemitraan sinergitas pemerintah dengan non-goverment organization (NGO) dalam pengendalian tuberkulosis paru di Kota Makassar [Strategic partnership between governments and NGOs in lung tuberculosis in Makasar City]. Makassar: Hasanuddin University; 2013.

16. Davidson H, Schluger NW, Feldman PH, Valentine DP, Telzak EE LF. The effects of increasing incentives on adherence to tuberculosis directly observed therapy. International Journal of Tubercolosis and Lung Disease. 2005; 4(9): 860-865.

17. Auer C, Lagahid JY, Tanner M, et al. Diagnosis and management of tuberculosis by private practitioners in Manila, Philippines. Health Policy (New York). 2006; 77: 172-181.

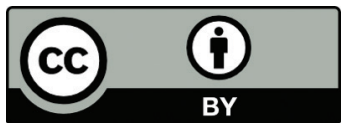

This work is licensed under a Creative Commons Attribution 